\title{
Kompetensi Manajerial Kepala Madrasah dalam Mengembangkan Kinerja Tenaga Pendidik dan Tenaga Kependidikan
}

\author{
Imron $^{1 *}$, Purwanto ${ }^{2}$, Yusuf Rohmadi ${ }^{3)}$ \\ 1,2,3 Institut Agama Islam Negeri (IAIN) Surakarta \\ *Email korespondensi: imron@ gmail.com
}

This study aims to determine the managerial competence of madrasah principals in developing the performance of teachers and education personnel (management study of the principal of Madrasah Aliyah Negeri 1 Pati in Pati Regency). This research was conducted on the implementation of pedagogic competence development at Madrasah Aliyah Negeri 1 Pati which was carried out by the head of madrasah to develop the performance of teaching staff and education personnel. The methodology in this study uses a qualitative approach. Data collection techniques in this study are by observation, interviews and documentation. The method used to check the validity of the data is the triangulation method. Data analysis in this study used qualitative analysis. The results showed that the Principal of Madrasah Aliyah Negeri 1 Pati management of pedagogic competence development at Madrasah Aliyah Negeri 1 Pati included: a) Planning for the head of the madrasah in developing the competence of teachers and education personnel at Madrasah Aliyah Negeri 1 Pati by preparing a work program that was initiated. by deliberation with the teaching staff and education staff in accordance with the regulations set by the government. b) The organizing that was carried out by the Head of Madrasah Aliyah Negeri 1 Pati was to realize the school development policy, especially the development of the competence of teachers and education staff in forming a work team for the quality of decision making. $c$ ) the implementation of the Principal of Madrasah Aliyah Negeri 1 Pati, where teaching staff and education personnel realize several main aspects in the program of competency development for teaching staff and education personnel, by disseminating the implementation of competency development for teachers and education personnel, d) Supervision of the Head of Madrasah Aliyah Negeri 1 Pati realized all the activities that were attended by educators and education staff in developing the competencies they mastered.

Keywords: managerial competence, principal of madrasah, performance, teaching staff, education staff

Saran sitasi: Imron., Purwanto., \& Rohmadi, Y. (2021). Kompetensi Manajerial Kepala Madrasah dalam Mengembangkan Kinerja Tenaga Pendidik dan Tenaga Kependidikan. Jurnal Ilmiah Ekonomi Islam, 7(01), 350359. doi: http://dx.doi.org/10.29040/jiei.v7i1.2228

\section{DOI: http://dx.doi.org/10.29040/jiei.v7i1.2228}

\section{PENDAHULUAN}

Madrasah merupakan lembaga pendidikan Islam yang menjadi cermin bagi umat Islam. Fungsi dan tugas madrasah adalah merealisasikan cita-cita umat Islam yang menginginkan anak-anak mereka dididik menjadi manusia beriman dan berilmu pengetahuan (Muhaimin, 1993: 35). Kualitas pendidikan madrasah bergantung pada banyak faktor seperti kepemimpinan kepala sekolah dan faktor pendukung lainnya yang berperan penting dalam menjaga dan menjamin kualitas pendidikan madrasah (Nursaid, 2020). Kompetensi kepala madrasah sangat membantu lembaga untuk menggambarkan bagaimana kinerja seorang kepala madrasah. Hal ini tentunya terkait dengan pengetahuan, keterampilan, dan kemampuan seorang kepala madrasah. Kompetensi merupakan dimensi penting dari pekerjaan kepala madrasah. Dari kompetensi itulah, kepala madrasah harus mengetahui bagaimana bertanggung jawab, memecahkan masalah, dan mentransfer informasi kepada guru, terkait dengan pelaksanaan tugas yang diinstruksikan (Hosnan, 2019).

Kompetensi manajerial adalah kemampuan yang berhubungan dengan tugas-tugas pengelolaan, pengawasan dan pengembangan orang (Zwell \& Lubausky, 2000). Kompetensi manajerial adalah 


\section{Jurnal Ilmiah Ekonomi Islam, 7(01), 2021, 351}

kemampuan dalam melaksanakan fungsi planning (perencanaan), organizing (pengorganisasian), leading (kepemimpinan atau pengarahan) dan controlling (pengendalian) pada seluruh sumber daya secara efektif dan efisien (Robbins, 2011); (lahir, et. al., 2017). Kepemimpinan manajerial mengasumsikan bahwa fokus kepemimpinan seharusnya terletak pada fungsi, tugas, dan perilaku dan jika fungsi tersebut dijalankan sepenuhnya maka pekerjaan orang lain dalam organisasi akan difasilitasi. Kepemimpinan dengan gaya manajerial ini mengharuskan setiap bagian dari organisasi madrasah diposisikan dengan benar sehingga tujuan madrasah tercapai (Bush, 2008). Jadi dapat disimpulkan bahwa kompetensi manajerial kepala madrasah didefinisikan sebagai kemampuan kepala madrasah dalam mengimplementasikan fungsi-fungsi manajemen yang diwujudkan melalui berbagai aktivitas belajar mengajar di sekolah mulai dari proses perencanaan, pengorganisasian, pelaksanaan, pengawasan, dan evaluasi yang dikoordinatori oleh kepala madrasah. Manajemen mempunyai tugas-tugas khusus yang harus dilaksanakan yang biasa disebut sebagai fungsifungsi manajemen: planning (perencanaan), organizing (pengorganisasian), motivating (pemberian motivasi), controlling (pengendalian), dan evaluating (penilaian) (Siagian, 2016).

Kepala madrasah dituntut memiliki kompetensi manajerial yang tinggi agar mampu mengambil keputusan dan inisiatif/prakarsa untuk meningkatkan kualitas madrasah (Asmendri, et.al., 2018). Kompetensi manajerial kepala madrasah adalah kemampuan kepala madrasah dalam mengelola sumber daya organisasi berdasarkan kompetensi yang ditetapkan dalam rangka mencapai tujuan yang telah ditentukan (Wahyudi, et. al., 2012). Kinerja guru tidak terlepas dari paradigma pengelolaan pendidikan yang memberikan kewenangan kepada kepala sekolah untuk melakukan perencanaan, pengorganisasian, pemantauan, dan pengendalian pendidikan. pendidikan di sekolah. Ada beberapa bentuk kompetensi manajerial kepala madrasah di antaranya: 1) sebagai pelaksana pendidikan; 2) guru yang diberitugas tambahan sebagai pimpinan sekolah; 3) mengelola administrasi sekolah guna mendukung pembelajaran yang efektif; 4) meningkatkan kompetensi profesional pendidik dan tenaga kependidikan; 5) mempengaruhi orang lainagar secara bersama-sama mencapai tujuan; dan 6) memberikan dorongan sebagai penggerak. Rangkaian kegiatan yang cukup banyak, menjadikan setiap tenaga pendidik dan kependidikan memiliki tujuan yang berbeda dalam menjalankan tugas dan fungsinya masing-masing. Kepala madrasah harus mampu meningkatkan kemampuannya secara terus menerus agar mampu menjalankan tugas, peran, dan fungsinya serta mampu mengarahkan, menggerakkan, dan mampu memberdayakan sumber daya yang ada terutama seluruh tenaga kependidikan melalui kerjasama untuk mencapai tujuan madrasah. Kepala madrasah harus mampu mendorong para tenaga pendidik dan tenaga kependidikan untuk meningkatkan motivasi kerja dalam melaksanakan tugas pokok dan fungsinya untuk mencapai tujuan madrasah sesuai dengan visi dan misi madrasah (Arianto, et.al., 2018).

Asmendri, et.al., (2018) secara umum kompetensi manajerial kepala madrasah yang diteliti tergolong baik pada semua aspek, yaitu terdiri dari aspek perencanaan kegiatan madrasah, pengorganisasian kegiatan, kepemimpinan, menggerakkan, dan pengendalian aktivitas. Sodiqin dan Nurdin (2016) kemampuan manajerial kepala Madrasah Aliyah dapat diukur dari empat dimensi yaitu: planning, organizing, actuating, dan controling. Namun pada dimensi kontrol atau pengawasan masih terbilang rendah apabila dibandingkan dengan dimensi lainnya. Susanti \& Kasturi (2017) menyatakan selama ini fokus pelaksanaan supervisi lebih mengarah pada aspek akademik dan fokus pada guru. Oleh karena itu, pengembangan model supervisi yang menekankan pada penguatan kompetensi kepala madrasah tsanawiyah sangat diperlukan. Hal tersebut dilakukan dengan memperluas fokus dan tujuan pembinaan, tidak hanya pada aspek akademik (tenaga pendidik), tetapi juga pada aspek manajerial dan peningkatan sumber daya manusia (tenaga kependidikan) secara keseluruhan melalui manajemen kolaboratif.

Madrasah Aliyah Negeri 1 Pati merupakan salah satu madrasah aliyah negeri yang berada di Kabupaten Pati yang mempunyai banyak prestasi baik di tingkat Kabupaten maupun Provinsi serta menjadi menjadi model serta rujukan bagi sekolah di sekitarnya. Salah satu keunggulannya tersebut yaitu manajerial kepala sekolahnya dalam mengembangkan kinerja tenaga pendidik dan tenaga kependidikan yang menjadi tanggungjawabnya. Meskipun demikian, berdasarkan data hasil observasi yang dilakukan di Madrasah Aliyah Negeri (MAN) 1 Pati ditemukan fakta bahwa 
sebagian besar guru sudah dapat memenuhi indikator penilaian kinerja guru, tenaga administrasi sekolah juga sudah bekerja dengan baik. Namun, masih ada beberapa guru yang masih memerlukan bimbingan dan pengarahan dari kepala madrasah agar kinerjanya dapat meningkat termasuk tenaga kependidikannya.

Berdasarkan latar belakang masalah di atas, peneliti tertarik melakukan penelitian kompetensi manajerial kepala madrasah dalam mengembangkan kinerja tenaga pendidik dan tenaga kependidikan (studi manajemen kepala Madrasah Aliyah Negeri 1 Pati di Kabupaten Pati).

\section{KAJIAN TEORI}

\subsection{Kompetensi Pedagogik}

Secara etimologis atau asal usul kata, pedagogi merupakan bahasa Yunani dari kata paedos (anak) dan dari kata agagos (membimbing/mengantar). Oleh karena itu, pedagogi berarti membimbing atau mengantar anak menuju yang dicita-citakan. Tugas membimbing/mengantar ini tentunya sangat melekat sekali dalam jati diri dan watak pendidik. Dengan demikian, pedagogi bermakna segala upaya yang dilakukan pendidik untuk membimbing/mengantar anak muda menjadi dewasa serta matang (Payong, 2011). Kompetensi pedagogik sendiri merupakan suatu kemampuan secara teknis dalam menjalankan setiap tugas yang diemban sebagai seorang pendidik, seorang pengajar, serta seorang pembimbing bagi anak didiknya. Kompetensi pedagogik sendiri juga dapat diartikan merupakan kemampuan guru berkaitan dengan pemahaman terhadap para peserta didik serta proses pengelolaan pembelajaran yang sifatnya mendidik dan dilakukan secara dialogis antara pendidik dan peserta didik. Secara substantif atau nomina, kompetensi berarti mencakup beberapa hal yaitu kemampuan pemahaman terhadap para anak didiknya, perancangan serta pelaksanaan proses kegiatan pembelajaran, evaluasi secara menyeluruh dari hasil belajar yang telah dicapai, dan pengembangan dari para peserta didik untuk senantiasa mengaktualisasikan/mengimplementasikan berbagai potensi yang dimiliki para peserta didik tersebut (Situmorang, 2009).

Kompetensi pedagogik yaitu kemampuan yang dimiliki seorang guru dalam melakukan kegiatan pengelolaan proses pembelajaran kepada para peserta didiknya. Selain itu, konteks kemampuan pedagogik juga dapat diwujudkan dan ditunjukkan dalam membantu peserta didik, membimbing peserta didik, serta memimpin peserta didiknya dengan maksimal dan sebaik mungkin. Permendiknas Nomor.16 Tahun 2007 tentang Standar Pendidik dan Kependidikan dikemukakan bahwa kompetensi pedagogik merupakan kemampuan guru dalam pengelolaan pembelajaran siswa yang setidaknya meliputi berbagai hal berikut ini (Suprihatiningrum, 2013): pemahaman terhadap wawasan/ atau landasan kependidikan, pemahaman terhadap peserta didiknya, perancangan kegiatan pembelajaran, pelaksanaan pembelajaran bersifat mendidik dan dialogis antara pendidik dan peserta didik, pemanfaatan teknologi proses belajar mengajar, valuasi dari hasil belajar yang telah dicapai, dan pengembangan para peserta didik untuk merealisasikan berbagai potensi yang mereka miliki.

2.2. Kompetensi Manajerial Kepala Madrasah

Musfah (2009) menyatakan kompetensi adalah kemampuan yang dimiliki oleh seseorang baik berupa pengetahuan, sikap,keterampilan dan diwujudkan dalan bentuk hasil kerja nyata yang dapat memberikan manfaat baik bagi dirinya sendiri maupun orang lain.Kompetensi menurut Pasal 1 ayat 10 UndangUndang Nomor 14 tahun 2005 tentang Guru dan Dosen menyatakan bahwa kompetensi adalah seperangkat pengetahuan, keterampilan, dan perilaku yang harus dimiliki, dihayati,dan dikuasai oleh guru atau dosen dalam melaksanakan tugas keprofesionalan.

Manajemen adalah prosesmengkoordinasikan dan mengintegrasikan kegiatan kerja agar diselesaikan secaraefektif dan efisien dengan melalui orang lain. Kompetensi manajerial adalah kemampuan dalam melaksanakan fungsi planning (perencanaan), organizing (pengorganisasian), leading (kepemimpinan atau pengarahan) dan controlling (pengendalian) pada seluruh sumber daya secara efektif dan efisien (Robbins, 2011). Stoner (1992) manajemen merupakan proses perencanaan, pengorganisasian, pengarahan dan pengawasan usahausaha pra anggota organisasi dan penggunaan sumber daya organisasi lainnya agar mencapai tujuan organisasi yang telah ditetapkan (Komariah, 2014). Dapat disimpulkan bahwa kompetensi manajerial kepala madrasah didefinisikan sebagai kemampuan kepala madrasah dalam mengimplementasikan fungsi-fungsi manajemen yang diwujudkan melalui berbagai aktivitas belajar mengajar di sekolah mulai dari prosesperencanaan, pengorganisasian, pelaksanaan, pengawasan, dan evaluasi. Sejalan 


\section{Jurnal Ilmiah Ekonomi Islam, 7(01), 2021, 353}

dengan pendapat Iskandar (2017) kemampuan manajerial adalah kemampuanseseorang dalam mengelola sumber daya organisasi berdasarkan kompetensiyang ditetapkan dalam rangka mencapai tujuan yang telah ditentukan.

Atmodiwirio dalam Sodiqin dan Nurdin (2016) menyatakan kompetensi atau kemampuan manajerial adalah seperangkat keterampilan teknis dalam melaksanakan tugas sebagai manajer sekolah untuk memperdayagunakan segala sumber yang tersedia untuk mencapai tujuan sekolah secara efektif danefesien. Jadi kemampuan manajerial kepala sekolah adalah kemampuan untuk memanajemen sekolah, mengorganisasikan orang dan sumber,mempergunakan tenaga-tenaga yang baik dan teknik kehumasan yang baik, memanfaatkan komunikasi yang efektif dalam menghadapi beraneka macam subjek yang berkepentingan, seperti orang tua murid atau siswa dan guru-guru.

Mengacu pada pendapat Stoner, et. al., (1992) dan Robbins (2011), kompetensi manajerial kepala sekolah dapat dipaham sebagai kemampuan kepala sekolah melaksanakan fungsi planning (perencanaan), organizing (pengorganisasian), leading (kepemimpinan atau pengarahan) dan controlling (pengendalian) pada seluruh sumber daya sekolah secara efektif dan efisien.

\section{a. Planning (Perencanaan)}

Perencanaan adalah fungsi fundamental manajemen karena pengorganisasian, pengarahan atau penggerakan dan pengendalian harus didahului dengan perencanaan. Kegiatan perencanaan mencakup mendefinisikan sasaran organisasi, menetapkan strategi menyeluruh untuk mencapai sasaran itu, dan menyusun serangkaian rencana yang menyeluruh untuk mengintegrasikan dan mengkoordinasikan pekerjaan organisasi (Robbins, 2011). Thoha (2004) perencanaan yang dilakukan oleh kepala madrasah adalah langkahlangkah meliputi: a) menetapkan visi, misi, tujuan, dan strategi pengembangan sekolah, b) menganalisis kekuatan, kelemahan, peluang, dan ancaman sekolah, c) mengembangkan rencana atau serangkaian kegiatan untuk pencapaian tujuan, d) mengembangkan berbagai alternatif kegiatan untuk pencapaian tujuan, penilaian alternatifalternatif tersebut dan pemilihan alternatif terbaik (paling memuaskan) diantara berbagai alternatif yang ada.

b. Organizing (Pengorganisasian)
Langkah pengorganisasian dilakukan agar semua sumber daya agar dapat berdaya guna secara maksimal untuk mendukung pencapaian sasaran yangtelah ditetapkan. Thoha (2004) mengatakan bahwapengorganisasian merupakan suatu proses untukmerancang struktur formal, mengelompokkan, mengatur serta membagi tugastugas atau pekerjaan diantarapara anggota organisasi, agar tujuan organisasi dapat dicapai dengan efisien. Pengorganisasian bagi kepala madrasah mencakup kegiatan: 1) menetapkan tugas-tugas yang harus dikerjakan, 2) personel yang harus mengerjakan, 3) mengelompokkan tugas-tugas, 4) menentukan siapa melapor kepada siapa, dan 5) dimanakeputusan harus diambil.

c. Leading (Kepemimpinan)

Kepemimpinan dipahami sebagai seni dan juga proses mempengaruhi dalampenentuan tujuan organisasi, pemotivasian dan penggerakan orang untuk untuk mencapai tujuan organisasi. Kepemimpinan kepala sekolah harus kreatif dan proaktif terhadap perubahan efektif dan berorientasi pada perbaikan mutu berkelanjutan". Itu artinya kepemimpinan disadari sebagai satu fungsi penting dalammanajemen guna pencapaian suatu tujuan. Kepemimpinan kepala sekolah merupakan sikap dan tindakankepala sekolah untuk menggerakkan orang lain ke arah pencapaian tujuan sekolah. Kepemimpinan kepalasekolah dibutuhkan untuk memberikan pemahaman, membangun kemauan atau motivasi, serta mengembangkan kemampuan komunitas sekolah dalam mengimplementasikan setiap rencana peningkatanmutu sekolah. Lebih dari itu, kepemimpinan kepala sekolah sangat dibutuhkan untuk melembagakan setiap nilai-nilai mutu. Sikap, perilaku, dan kebijakan kepala sekolah akan menjadi barometer seberapa tinggi nilai-nilai mutu ingin dilembagakan.

d. Controlling (Pengendalian)

Pengendalian adalah memantau kegiatan-kegiatan untuk memastikan kegiatan itu dicapai sesuaidengan yang direncanakan dan mengoreksi setiap penyimpangan yang berarti (Robbins, 2011). Langkah-langkah pengendalian adalah dengan memantau kegiatan-kegiatan untuk memastikan kegiatan tersebut tercapai sesuai dengan perencanaanyang telah ditentukan. Pengendalian dilakukan untuk menjamin bahwa tujuan-tujuan organisasi dan manajemen tercapai. 


\subsection{Manajemen Pendidikan Islam}

Tujuan serta manfaat manajemen dalam penyelenggaraan pendidikan adalah untuk mencapai dan meningkatkan efektivitas, efisiensi dan produktivitas kerja dalam mencapai tujuan pendidikan yang diinginkan. Efektivitas adalah suatu keadaan yang mengandung pengertian mengenai teriadinya efek atau hasil yang dikehendaki. Jadi suatu pekerjaan dikatakan efektif, jika pekerjaan tersebut mencapai atau tujuan yang telah ditentukan. Efektivitas umumnya merujuk pada pencapaian tujuan. Manajemen merupakan suatu rangkaian kegiatan kepengurusan, ketatalaksanaan penggunaan sumber daya untuk mencapai sasaran atau tujuan pokok yang telah ditentukan dengan menggunakan orang-orang pelaksana dalam suatu hubungan kerjasama. Manajemen adalah suatu rangkaian tindakan dengan maksud untuk mencapai hubungan kerjasama yang rasional dalam suatu sistem administrasi (Fathul Jannah, 2015).

Manajemen pendidikan merupakan proses pengembangan kegiatan kerjasama sekelompok orang untuk mencapai tujuan pendidikan yang telah ditetapkan (Mulyasa, 2003). Manajemen pendidikan adalah semua bentuk usaha bersama untuk mencapai tujuan pendidikan itu dengan merancang, mengadakan, dan memanfaatkan sumber-sumber (Komariah, 2014). Manajemen atau administrasi pendidikan merupakan aplikasi ilmu administrasi dalam kegiatan pembinaan, pengembangan dan pengendalian usaha-usaha pendidikan yang diselenggarakan dalam bentuk kerjasama sejumlah orang dengan menggunakan segala sarana dan prasarana yang tersedia baik moral material dan spiritual agar tercapainya tujuan pendidikan secara efektif dan efisien. Karena itu, administrasi pendidikan merupakan serangkaian kegiatan atau proses yang berkelanjutan menggunakan prinsipprinsip administrasi. Kegiatan administrasi pendidikan dalam rangka memanfaatkan semua potensi atau sumber daya yang tersedia, untuk mencapai tujuan yang diperjuangkan agar terpenuhi secara efektif dan efisien. Kegiatan atau aktivitas yang tergolong pada jenis yang sama berdasarkan sifatnya ataupun pelaksanaannya disebut fungsi. Aktivitasaktivitas tersebut digabungkan menjadi satu kesatuan dan diserahkan menjadi tanggung jawab seseorang yang bertanggung jawab terhadap organisasi tertentu (Hasbiyallah, 2019).
Mustari \& Rahman (2014), mengemukakan bahwa manajemen pendidikan merupakan suatu proses yang merupakan daur (siklus) penyelenggaraan pendidikan dimulai dari perencanaan, diikutioleh pengorganisasian, pengarahan, pelaksanaan, pemantauan, danpenilaian tentang usaha sekolah untuk mencapai tujuannya. Manajemen pendidikan merupakan usaha untuk melakukan pengelolaan sistem pendidikan. Manajemen pendidikan merupakan kegiatan memimpin, mengambil keputusan serta berkomunikasi dalam organisasi sekolah sebagai usahauntuk mencapai tujuan pendidikan. Manajemen pendidikan Islam adalah suatu proses penataan/ pengelolaan lembaga pendidikan Islam yang melibatkan sumber daya manusia muslim dan non muslim dalam menggerakkannya untuk mencapai tujuan pendidikan Islam secara efektif dan efisien (Ariyanto \& Sulistyorini, 2020). Manajemen pendidikan Islam adalah proses pemanfaatan semua sumber daya yang dimiliki (ummat Islam, lembaga pendidikan atau lainnya) baik perangkat keras maupun lunak. Pemanfaatan tersebut dilakukan melalui kerjasama dengan orang lain secara efektif, efisien, dan produktif untuk mencapai kebahagiaan dan kesejahteraan baik di dunia maupun di akhirat (Kosim \& Ramayulis, 2012).

Tujuan utama manajemen pendidikan Islam adalah: 1) Untuk dapat meningkatkan efisiensi dan efektifitas penyelenggaraan kegiatan operasional pendidikan dalam mencapai tujuan pendidikan Islam. 2) Untuk dapat mengembangkan karakter dan kemampuan peserta didik agar menjadi warga negara yang memiliki kualitas, sesuai dengan cita-cita bangsa berdasarkan Pancasila dan Undang-undang Dasar 1945 (Hasbiyallah, 2019).

Prinsip-prinsip manajemen pendidikan adalah sebagai berikut (Hasbiyallah, 2019):

a. Prinsip fleksibilitas, dalam penyelenggaraan pendidikan di sekolah hendaknya dilakukan dengan mengingat faktor-faktor dan kemampuan untuk menyediakan fasilitas bagi berlangsungnya program pendidikan di sekolah.

b. Prinsip kerjasama, seseorang manager akan berhasil baik dalam tugasnya bila ia mampu mengembangkan kerjasama di antara orang-orang yang terlibat, baik secara horizontal maupun secara vertikal. 


\section{Jurnal Ilmiah Ekonomi Islam, 7(01), 2021, 355}

c. Prinsip efisiensi, seorang manager akan berhasil dalam tugasnya bilamana dia efisien dalam menggunakan semua sumber tenaga, dana dan fasilitas yang ada.

d. Prinsip kepemimpinan yang efektif, seorang manager yang berhasil dalam tugasnya apabila ia menggunakan gaya kepemimpinan yang efektif, yakni yang memperhatikan dimensi-dimensi hubungan antar manusia(human relationship), dimensi pelaksanaan tugas dan dimensi situasi dan kondisi (sikon) yang ada, serta dimensi spiritual.

e. Prinsip berorientasi pada tujuan, sesuai dengan pendekatan sistem maka semua kegiatan pendidikan harus berorientasi pada tujuan. Karena manager pendidikan di sekolah merupakan komponen dalam sistem pendidikan maka untuk menjamin tercapainya tujuan tersebut, tujuan operasional yang sudah dirumuskan itu juga menjadi gantungan orientasi bagi pelaksanaan kegiatan management pendidikan di sekolah.

f. Prinsip Berkelanjutan, merupakan landasan operasional dalam melaksanakan kegiatan sebagaimana pendidikan di sekolah. Karena itu, dalam tiap jenjang pendidikan harus memiliki hirarki yang saling berhubungan.

g. Prinsip Pendidikan Sepanjang Hayat, setiap manusia Indonesia diharapkan untuk selalu berkembang. Karena itu baik masyarakat ataupun pemerintah diharapkan dapat menciptakan situasi yang mendukung dalam proses pembelajaran. Dalam melaksanakan manajemen pendidikan, prinsip tersebut perlu digunakan sebagai landasan operasional.

h. Prinsip Pengelolaan, administrator akan memperoleh hasil yang paling efektif dan efesien dengan cara melakukan pekerjaan manajemen, yakni merencanakan, mengorganisasikan, mengarahkan dan melakukan pemeriksaan (pengontrolan).

i. Prinsip Ikhlas, prinsip ikhlas merupakan motivasi bagi setiap tenaga manajemen dalam melaksanakan tugas yang diambilnya. Dengan prinsip ikhlas karena Allah maka aktivitas manajemen pendidikan akan bernilai ibadah. Dengan prinsip ini seorang manager akan mendapat dua imbalan yaitu: (1) imbalan berupa materil dari organisasi tempat ia bekerja, dan (2) imbalan dari Allah SWT berupa pahala yang akan diterima di akhirat.
Keberadaan kepala madrasah sebagai seorang manajer mempunyai peran yang signifikan dalam rangka mengembangkan dan memberdayakan berbagai sumber daya yang ada dalam mencapai tujuan yang telah ditetapkan (Safitri \& Oktaviana, 2017). Kepala madrasah sebagai pemimpin pendidikan di sekolah menjadi orang yang mempunyai tanggung jawabdalam penyelenggaraan manajemen pendidikan di madrasah. Untuk mewujudkan sebuah madrasah yang agamis dan melahirkan lulusan-lulusan yang berkualitas danberkompeten sesuai dengan standar kelulusan nasional, maka sudah pasti diperlukansosok kepala madrasah yang berkualitas pula. Kepala madrasah harus memiliki berbagai kompetensi yang memadai serta diperlukan sebagai modal dalam melaksanakan tugas dan tanggung jawab atas kepemimpinan yang diembannya, hal itu dilakukan dalam rangka untuk mewujudkan kinerja tenaga pendidik dan tenaga kependidikan yang semakin baik dan terus meningkat. 2.4. Kinerja Tenaga Pendidik dan Tenaga Kependidikan

Menurut Mangkunegara \& Prabu (2004), istilah kinerja berasal dari kata job performance atau actual performance yaitu prestasi kerja atau prestasi sesunggunhnya yang dicapai oleh seseorang. Hasibuan (2012) kinerja atau prestasi kerja adalah suatu hasil kerja yang dicapai seseorang dalam melaksanakan tugas-tugas yang dibebankan kepadanya yang didasarkan atas kecakapan, pengalaman, dan kesungguhan serta waktu. Dapat disimpulkan bahwa kinerja adalah kemampuan yang ditunjukkan oleh seseorang dalam melaksanakan tugas atau pekerjaannya. Kinerja dalam lingkup institusi pendidikan melibatkan seluruh sumber daya manusia baik tenaga pendidikan maupun tenaga kependidikan yang ada di sekolah tersebut.

Menurut Pasal 1 Undang-undang No. 20 tahun 2003 tentang Sistem Pendidikan Nasional dinyatakan bahwa tenaga kependidikan adalah anggota masyarakat yang mengabdikan diri dan diangkat untuk menunjang penyelenggaraan pendidikan. Sementara pendidik adalah tenaga kependidikan yang berkualifikasi sebagai guru, dosen, konselor, pamong belajar, widyaiswara, tutor, instruktur, fasilitator, dan sebutan lain yang sesuai dengan kekhususannya, serta berpartisipasi dalam menyelenggarakan pendidikan. Dari definisi tersebut jelas bahwa tenaga kependidikan memiliki lingkup profesi yang lebih luas, yang juga mencakup di dalamnya tenaga pustakawan, staf 
administrasi, staf pusat sumber belajar. Jadi tenaga pendidik yang dimaksud dalam penelitian ini adalah guru, sedangkan tenaga kependidikan meliputi tenaga adminsitrasi sekolah di bawah kepemimpinan kepala sekolah.

Kinerja tenaga pendidik (guru) menurut Bamawi dan Arifin (2012) adalah tingkat keberhasilan guru dalam melaksanakan tugas pendidikan sesuai dengan tanggung jawab dan wewenangnya berdasarkan standar kinerja yang telah ditetapkan selama periode tertentu dalam rangka mencapai tujuan pendidikan. Supardi (2013) kinerja guru adalah kemampuan kerja guru dalam menjalankan tugas dan tanggung jawabnya sebagai seorang pendidik dengan membina peserta didik guna meningkatkan prestasi belajarnya. Hal ini sesuai dengan Peraturan Menteri Pendidikan dan Kebudayaan Nomor 22 Tahun2016 tentang Standar Proses untuk Satuan Pendidikan Dasar dan Menengah, yang meliputi perencanaan proses pembelajaran, pelaksanaan proses pembelajaran, penilaian hasil pembelajaran, dan pengawasan pembelajaran. Menurut Supardi (2013) kinerja guru dapat diukur melalui indikator sebagai berikut:

a. Kemampuan menyusun rencana pembelajaran

b. Kemampuann melakukan pembelajaran

c. Kemampuann melakukan penilaian hasil belajar

d. Kemampuann mengelola hubungan antar pribadi

e. Kemampuann melakukan program pengayaan

Sedangkan kinerja tenaga kependidikan merujuk pada Rivai dan Basri (2005) kinerja karyawan adalah hasil atau tingkat keberhasilan seseorang secara keseluruhan selama periode tertentu dalam melaksanakan tugas dibandingkan dengan berbagai kemungkinan, seperti standar hasil kerja, targetatau sasaran yang telah ditentukan dan telah disepakati bersama. Manajemen kinerja ditujukan untuk meningkatkan aspek-aspek kinerja yang meliputi: sasaran yang dicapai; kompetensi yang meliputi pengetahuan, keterampilan, sikap, serta efektifitas kerja.

\section{METODOLOGI PENELITIAN}

Penelitian ini menggunakan pendekatan kualitatif. Arikunto (2006), menyatakan penelitian kualitatif dimaksudkan untuk mengumpulkan data atau informasi mengenai keadaan sesuatu gejala dan untuk memperoleh kesimpulan, data yang telah terkumpul dipisah-pisahkan menurut masing-masing kategori dan diwujudkan dengan kata-kata atau kalimat. Tujuan penelitian kualitatif adalah untuk memahami keunikan. Penelitian ini menggunakan metode penelitian kualitatif, karena dilakukan untuk memahami keunikan. Keunikan yang hendak dipahami dari penelitian ini adalah mengapa madrasah menyediakan sarana TIK untuk pembelajaran, tetapi guru belum memanfaatkannya untuk pembelajaran. Penelitian kualitatif dalam penelitian ini berusaha menggambarkan pelaksanaan kompetensi manajerial kepala madrasah, yaitu kepala Madrasah Aliyah Negeri 1 Pati.

Teknik pengumpulan data pada penelitian ini yaitu dengan observasi, wawancara dan dokumentasi. Metode yang digunakan untuk memeriksa keabsahan data adalah dengan triangulasi method yaitu dengan memanfaatkan berbagai metode sebagai pertimbangan. Triangulasi ini dilakukan dengan jalan membandingkan dan mengecek informasi atau data yang diperoleh dari dokumentasi dengan hasil pengamatan dan interview (Moleong, 2014). Triangulasi ini dilakukan dengan; (1) membandingkan data hasil pengamatan dengan data hasil wawancara, (2) membandingkan apa yang dikatakan orang di depan umum dengan yang dikatakan pribadi, (3) membandingkan apa yang dikatakan orang tentang situasi penelitian dengan apa yang didapat selama penelitian, (4) membandingkan keadaan dan perspektif seseorang dengan berbagai pendapat dan pandangan yang lain, dan (5) membandingkan hasil wawancara dengan isi suatu dokumen yang berkaitan.

Analisis data dalam penelitian ini menggunakan analisa kualitatif. Menurut Milles dan Huberman (2012) proses analisa data menggunakan teknik analisis data model interaktif (interactive model of analysis) yang terdiri dari empat komponen analisa data, yaitu pengumpulan data, reduksi data, penyajian data dan penarikan kesimpulan.

\section{HASIL PENELITIAN}

Pelaksanaan pembinaan kompetensi pedagogik di Madrasah Aliyah Negeri 1 Pati yang dilakukan oleh kepala madrasah untuk mengembangkan kinerja tenaga pendidik dan tenaga kependidikan. Pelaksanaan pembinaan kompetensi pedagogik di Madrasah Aliyah Negeri 1 Pati yang dilakukan oleh kepala madrasah untuk mengembangkan kinerja tenaga pendidik dan tenaga kependidikan dimulai dari tahap perencanaan, pengorganisasian, pelaksanaan, dan pengawasan.

a. Perencanaan, perencanaan pembinaan kompetensi pedagogik disana dilaksanakan melalui tahapan 


\section{Jurnal Ilmiah Ekonomi Islam, 7(01), 2021, 357}

sebagai berikut:

1) Program pengerjaan perangkat pembelajaran. Penyusunan terhadap perangkat atau pengerjaan pembelajaran di Madrasah Aliyah Negeri 1 Pati meliputi: pembuatan Rencana Pelaksanaan Pembelajaran, silabus, program semester dan program tahunan, serta kalender pendidikan secara terstruktur dilakukan rutin setiap awal semester berjalan. Hal tersebut dilakukan oleh Kepala Madrasah Aliyah Negeri 1 Pati untuk mengantisipasi dinamisnya kebijakan pemerintah yang kecenderunggannya berubah sewaktu-waktu dalam memutuskan serta menetapkan kurikulum baru yang berlaku bagi sekolah. Ketika diadakan kegiatan rapat dewan guru, masing-masing tenaga pendidik harus berperan secara aktif sesuai dengan bidang masing-masing mereka. Setiap guru pada mata pelajaran tertentu membentuk kelompok dengan merancang berbagai program pembelajaran (MGMP). Mereka melaksanakan kegiatan rapat pada kelompok guru mapel untuk membahas rencana pembelajaran yang akan dilaksanakan nantinya, agar pelaksanakan pembelajaran sistematis dan terstruktur dengan rapi.

2) Program pelatihan atau workshop baik secara internal maupun secara eksternal bagi guru atau tenaga pendidik serta terhadap tenaga kependidikan Madrasah Aliyah Negeri 1 Pati. Perencanaan dan tahap pengelolaan proses belajar mengajar tentunya akan menjadi kendali yang penting sekali, dimana berbagai capaian sasaran mutu khususnya terhadap kualitas PBM sekaligus nilai tingkat kompetensi guru atau tenaga pendidik di Madrasah Aliyah Negeri 1 Pati akan terukur atau dapat diukur melalui hal tersebut. Begitu pula pelatihan atau workshop terhadap tenaga kependidikan di Madrasah Aliyah Negeri 1 Pati guna meningkatkan kompentensi serta kinerja tenaga kependidikan di Madrasah Aliyah Negeri 1 Pati yang pada akhirnya bermuara pula dalam menunjang mutu pendidikan yang ada di Madrasah Aliyah Negeri 1 Pati.

b. Pengorganisasian, setelah proses perencanaan, maka selanjutnya yaitu proses pengorganisasian. Langkah-langkah yang dilakukan Kepala Madrasah Aliyah Negeri 1 dalam pengorganisasian pembinaan kompetensi pedagogik tenaga pendidik dan tenaga kependidikan yaitu: 1) Melakukan identifikasi terhadap kualitas tenaga pendidik dan tenaga kependidikan melalui angket atau kuesioner untuk mengukur kepuasaan atas kerja yang mereka lakukan, 2) Pengelolaan program implementasi belajar mengajar (KBM), 3) Pengelolaan supervisi untuk guru, 4) Mengidentifiksi kualitas tenaga pendidik dan tenaga kependidikan melalui pelaksanaan pelatihan atau diklat.

c. Pelaksanaan, pelaksanaan pembinaan kompetensi pedagogik di Madrasah Aliyah Negeri 1 Pati dimana pelaksanaan Kepala Madrasah Aliyah Negeri 1 Pati merealisasikan beberapa aspek utama dalam progam pembinaan kompetensi tenaga pendidik dan tenaga kependidikan, dengan melakukan sosialisasi pelaksanaan pembinaan komptensi tenaga pendidik dan tenaga kependidikan. Pelaksanaan Kepala Madrasah Aliyah Negeri 1 Pati dalam rangka meningkatkan kompetensi pedagogik bagi para tenaga pendidik dan tenaga kependidikan di Madrasah Aliyah Negeri 1 Pati adalah sebagai berikut: 1) Pelaksanaan pendidikan dan diklat/pelatihan untuk guru Madrasah Aliyah Negeri 1 Pati cukup intensif mengadakan berbagai kegiatan pendidikan mupun pelatihan yang bersifat internal untuk meningkatkan profesionalisme para tenaga pendidik maupun tenaga kependidikannya, seperti mengikuti pelatihan administrasi guru maupun tenaga kependidkan, workshop pembelajaran bagi guru atau tenaga pendidik, pelatihan cara mengajar atau microteaching, kelompok diskusi bagi guru mapel, hingga berbagai seminar nasional yang bertujuan untuk meningkatkan kualitaskan kinerja tenaga pendidik dan tenaga kependidikan di Madrasah Aliyah Negeri 1 Pati, 2) Dukungan dari kepala madrasah untuk tenaga pendidik dan tenaga kependidikan yang melanjutkan studi dalam rangka mendukung mereka untuk memperdalam keilmuannya termasuk memberikan izin studi lanjut, 3) Dukungan kepala Madrasah Aliyah Negeri 1 Pati dalam program pengembangan kompetensi tenaga pendidik dan tenaga kependidikan dimana Kepala Madrasah Aliyah Negeri 1 Pati bekerjasama dengan wakil kepala bagian sarpras serta wakil kepala bagian kurikulum mendukung program pengembangan kompetensi untuk tenaga pendidik dan tenaga kependidikan dengan 


\section{Jurnal Ilmiah Ekonomi Islam, 7(01), 2021, 358}

melakukan pendataan peta kompetensi yang mereka miliki guna meningkatkan kinerja.

d. Pengawasan, berkaitan dengan pengawasan yang dilakukan Kepala Madrasah Aliyah Negeri 1 Pati untuk peningkatan kemampuan tenaga pendidik dan tenaga kependidikan, Kepala Madrasah Aliyah Negeri 1 Pati memiliki beberapa kegiatan pengawasan atau monitoring baik terhadap kinerja tenaga pendidik maupun tenaga kependidikan. Pengawasan terhadap tenaga pendidik atau guru sebagai berikut: 1) Pengawasan Kepala Madrasah Aliyah Negeri 1 Pati terhadap kinerja harian tenaga pendidik, dalam proses pengawasan kinerja tenaga pendidik atau guru dilakukan secara harian, kemudian selain kepala madrasah, wakil kepala (kurikulum) ikut mengawasai serta mengecek setiap guru mapel dalam mempersiapkan kegiatan belajar mengajar. 2) Kepala Madrasah Aliyah Negeri 1 Pati melakukan pengawasan melalui Penilaian Kinerja Guru dan Penilaian Kinerja Berkelanjutan, dimana dua hal itu merupakan produk penilaian maupun evaluasi yang terbaru yang telah digulirkan oleh pemerintah dalam rangka sebagai alat untuk melakukan evaluasi atas kinerja tenaga pendidik yang berlaku selama satu tahun akademik berjalan. 3) Kepala Madrasah Aliyah Negeri 1 Pati melakukan pengawasan melalui supervisi klinis, dimana kegiatan ini merupakan alat ukur evaluasi pra Penilaian Kinerja Guru (PKG) dan pra Penilaian Kinerja Berkelanjutan (PKB).

\section{KESIMPULAN}

Berdasarkan hasil penelitian, maka dapat disimpulkan bahwa Kepala Madrasah Aliyah Negeri 1 Pati manajemen pembinaan kompetensi pedagogik di Madrasah Aliyah Negeri 1 Pati meliputi: a) Perencanaan kepala madrasah dalam melakukan pembinaan terhadap kompetensi tenaga pendidik dan tenaga kependidikan di Madrasah Aliyah Negeri 1 Pati dengan melakukan persiapan program kerja yang diawali dengan musyawarah bersama tenaga pendidik dan tenaga kependidikan sesuai dengan aturan-aturan yang telah ditetapkan oleh pemerintah. b) Pengorganisasian yang dilakukan Kepala Madrasah Aliyah Negeri 1 Pati adalah dengan merealisasikan kebijakan pengembangan sekolah khususnya pembinaan kompetensi tenaga pendidik dan tenaga kependidikan dalam membentuk tim kerja untuk kualitas pengambian keputusan. c) pelaksanaan
Kepala Madrasah Aliyah Negeri 1 Pati, dimana tenaga pendidik dan tenaga kependidikan merealisasikan beberapa aspek utama dalam progam pembinaan kompetensi tenaga pendidik dan tenaga kependidikan, dengan melakukan sosialisasi pelaksanaan pembinaan komptensi tenaga pendidik dan tenaga kependidikan, d) Pengawasan Kepala Madrasah Aliyah Negeri 1 Pati merealisasikan semua kegiatan yang diikuti oleh tenaga pendidik dan tenaga kependidikan dalam membina kompetensi yang mereka kuasai.

\section{DAFTAR PUSTAKA}

Asmendri, A., Marsidin, S., Rusdinal, R., \& Mukhaiyar, M. (2018). An Analysis of Managerial Competence of the Madrasah Principals in Islamic Senior High School in Tanah Datar. Al-Ta Lim Journal, 25(1), 56-70.

Ariyanto, A., \& Sulistyorini, S. (2020). Konsep motivasi dasar dan aplikasi dalam lembaga pendidikan Islam. AL-ASASIYYA: Journal Of Basic Education, 4(2), 103-114.

Banawi \& Arifin (2012) Inventarisasi kegiatan pengelola sarana dan prasarana pendidikan.

Bush, T. (2008). Leadership and management development in education. Sage.

Hasbiyallah, H., Sulhan, M., Khoiruddin, H., \& Burhanudin, U. (2019). Memotret Wajah Islam Melalui Perguruan Tinggi Keagamaan Islam Negeri di Indonesia. Khazanah: Jurnal Studi Islam dan Humaniora, 17(2), 227-244.

Hosnan, M. (2019). Liberalisme dalam Pendidikan Islam. Jurnal Pemikiran dan Ilmu Keislaman, 2(1), 420-43

Iskandar, J. (2017). Keterampilan Manajerial Kepala Sekolah. Idaarah: Jurnal Manajemen Pendidikan, 1(1).

Jannah, F. (2015). Inovasi Pendidikan Dalam Rangka Peningkatan Kualitas Pembelajaran Melalui Penelitian Tindakan Kelas. -, 1(1).

Komariah, A. (2014). Pengaruh kepemimpinan transformasional, iklim sekolah, kinerja mengajar guru terhadap produktivitas sekolah. MIMBAR: Jurnal Sosial dan Pembangunan, 30(1), 118-125.

Kosim, M., \& Ramayulis, H. (2012). Pemikiran pendidikan Islam Ibn Khaldun: kritis, humanis dan religius. PT Rineka Cipta. 


\section{Jurnal Ilmiah Ekonomi Islam, 7(01), 2021, 359}

Lahir, S., Ma'ruf, M. H., \& Tho'in, M. (2017). Peningkatan Prestasi Belajar Melalui Model Pembelajaran Yang Tepat Pada Sekolah Dasar Sampai Perguruan Tinggi. Jurnal Ilmiah Edunomika, 1(01).

Mangkunegara, A. P., \& Prabu, A. (2004). Manajemen Sumber Daya Manusia, Cetakan Pertama. Bandung: PT. Remaja Rsodakarya.

Milles, M. B., \& Huberman, A. M. (2012). Quality Data Analysis: A. Source Book of New Method. Moleong, L. (2014). J, Metodologi Penelitian Kualitatif, PT. Remaja Rosdakarya.

Muhaimin, A. (1993). Mujib. Pemikiran Pendidikan Islam. Bandung, Indonesia: Trigenda Karya.

Mulyasa, E. (2003). Pedoman Manajemen Berbasis Madrasah. Jakarta: Departemen Agama RI.

Musfah, J. (2009). Metode Pendidikan dalam Perspektif Islam. dalam Jurnal Tahdzib.

Mustari, M., \& Rahman, M. T. (2014). Manajemen pendidikan.

Nursaid, N. (2020). The Leadership of Headmaster in Improving the Quality of Madrasa Education. Jurnal Pendidikan Islam, 6(1), 95108.

Payong, M. R. (2011). Sertifikasi profesi guru: konsep dasar, problematika, dan implementasinya. Indeks.

Rivai, V., \& Basri, A. F. M. (2005). Performance Appraisal: Sistem yang tepat untuk menilai kinerja karyawan dan meningkatkan daya saing perusahaan. PT RajaGrafindo Persada.

Robbins, P. (2011). Political ecology: A critical introduction (Vol. 16). John Wiley \& Sons.

Safitri, D., \& Oktaviana, M. (2017). Implementasi Penilaian Autentik Kurikulum 2013 (Studi Kasus Guru IPS di SMP Labschool Jakarta). Edukasi IPS, l(1), 31-40.
Siagian, M. D. (2016). Kemampuan koneksi matematik dalam pembelajaran matematika. MES: Journal of Mathematics Education and Science, 2(1).

Situmorang, J. B. (2009). Pendidikan Profesi dan Sertifikasi Pendidik. Klaten: Saka Mitra Kompetensi.

Sodiqin, H., \& Nurdin, D. (2016). Kemampuan manajerial kepala madrasah dan kinerja mengajar guru dalam mutu pendidikan. Jurnal Administrasi Pendidikan, 23(2).

Stoner, 1., Ma, G. H., Wolter, S. D., \& Glass, J. T. (1992). Characterization of bias-enhanced nucleation of diamond on silicon by invacuo surface analysis and transmission electron microscopy. Physical Review B, 45(19), 11067.

Suharsimi, A. (2006). metodelogi Penelitian. Yogyakarta: Bina Aksara.

Supardi. (2013). Penialain Terhadap Kinerja Guru dalam Meningkatkan Mutu Pembelajaran di Madrasah.

Suprihatiningrum, J. (2013). Guru profesional: pedoman kinerja, kualifikasi \& kompetensi guru. Ar-Ruzz Media.

Susanti, D., \& Kasturi, T. (2017). Hubungan Antara Persepsi Tentang Kesehatan Lingkungan Sekolah Dan Sikap Terhadap Otoritas Guru Dengan Minat Belajar Siswa (Doctoral dissertation, Universitas Muhammadiyah Surakarta).

Zwell, M., \& Lubawski, J. L. (2000). Board/CEO relations. Hiring the right management team. Trustee: the journal for hospital governing boards, 53(2), 24-26 